\title{
Relationship between air pollution and outpatient visits for nonspecific conjunctivitis in Taiwan
}

\author{
Yi-Horng Lai ${ }^{1}$
}

\begin{abstract}
Background: As a directly exposed part of the human body, the eyes are susceptible to external stimulations of air pollution. The ill effects of air pollution on human eyes are mostly irritation and inflammation, with conjunctivitis being a significant problem.

Method: This study investigates the impact of air pollution on nonspecific conjunctivitis based on the data from ophthalmologic outpatient visits. The research focuses on the significance of air pollution's impact on ocular health. Data for ophthalmology outpatient visits were obtained from the National Health Insurance Research Database of Taiwan. Ambient air monitoring data were obtained from the Taiwan Environmental Protection Administration air pollution monitoring stations. Six regulated air pollutants were included in the studies. This study used symbolic data analysis to investigate the association between daily air pollutant concentrations and the number of outpatient visits for nonspecific conjunctivitis as well as the relationship between climate factors and air pollutants.

Results: $\mathrm{O} 3$ ( $\mathrm{t}$-value $=2.292, \mathrm{p}$-value $=0.025$ ) is positively correlated with nonspecific conjunctivitis cases; this result is the same as plot $(\mathrm{d})$ in Figure 3 . The relationship between nonspecific conjunctivitis cases and CO ( $t$-value $=-1.183, p$-value $=0.240) / \mathrm{NO} 2(t-v a l u e=0.653, p$-value $=0.516) / \mathrm{NO} 2(\mathrm{t}$ value $=0.653, \mathrm{p}$-value $=0.516) / \mathrm{SO}(\mathrm{t}$-value $=-0.942, \mathrm{p}$-value $=0.349)$ is not statistically significant.

Conclusion: The result of this study shows that the air pollutant, $\mathrm{O}_{3}$ is significantly related to nonspecific conjunctivitis. The air pollutant, $\mathrm{O}_{3}$ can increase chances of outpatient visits, suggesting that is a possible cause for nonspecific conjunctivitis.
\end{abstract}

Keywords: air pollutants, particulate matter (PM), nonspecific conjunctivitis, climate factors, symbolic data analysis

\section{INTRODUCTION}

Air pollutions are correlated with many adverse health effects and diseases, and this is well recognized by many studies (1-5). WHO describes air pollution as "the contamination of the indoor or outdoor environment by any chemical, physical or biological agent that modifies the natural characteristics of the atmosphere (6)." Despite the recent legislations on air pollutant standards that are more stringent than before, air pollution is still a major concern and its impact on health is still present. More developed countries have paid high attention to the regulation of the air pollution, and there are comprehensive reviews and guidelines produced by organizations and governmental departments.

Previous studies were carried out on the correlation between air pollutants and health using a wide spectrum of mathematical and statistical modeling methods. Findings from most of the previous studies showed that air pollutants have negative influence on health. Studies on lung cancer (1,2), acute respiratory infection (3), liver cancer (4), and menstrual cycle (5) showed a significant correlation between health and air pollutants. Dense innervations in the ocular surface are extremely sensitive to environmental agents (7). Furthermore, the eyes are protected only by a thin layer of tear film from potentially damaging exterior influences (8). Thus, human eyes are very susceptible to ill effects of air pollution.

The ill effects of air pollution on human eyes are mostly irritation and inflammation, with conjunctivitis being a significant problem $(9,12-15)$. Many research investigations have attempted to discover the effects of environmental toxins on the ocular surface. Among persons living in high-polluted areas, a considerable portion suffers from subclinical ocular surface changes (12).

\footnotetext{
${ }^{1}$ Department of Health Care Administration, Oriental Institute of Technology, Taiwan.
}

(C) 2019 by the authors; licensee Modestum Ltd., UK. This article is an open access article distributed under the terms and conditions of the Creative Commons Attribution License (http://creativecommons.org/licenses/by/4.0/). 
Table 1: The results of previous studies about air pollutants' impact on nonspecific conjunctivitis

\begin{tabular}{ccccccc}
\hline & $\mathbf{C O}$ & $\mathbf{N O}_{\mathbf{2}}$ & $\mathbf{S O}_{\mathbf{2}}$ & $\mathbf{O}_{\mathbf{3}}$ & $\mathbf{P M}_{\mathbf{1 0}}$ & $\mathbf{P M}_{\mathbf{2 . 5}}$ \\
\hline Bourcier (2003) (9) & - & Yes & Yes & Yes & Yes & - \\
\hline Chang (2012) (12) & No & Yes & Yes & Yes & Yes & No \\
\hline Mimura (2014) (13) & No & No & - & - & - & Yes \\
\hline Szyszkowicz (2016) (14) & - & Yes & Yes & Yes & - & Yes \\
\hline Hong (2016) (15) & - & Yes & No & Yes & No & No \\
\hline
\end{tabular}

1. Yes: This air pollutant is a significant predictor of the number of outpatient visits.

2. No: This air pollutant is not a significant predictor of the number of outpatient visits.

3. -: This study didn't determine the effects of this air pollutant.

Conjunctivitis is one of the most commonly diagnosed conditions in ophthalmologic outpatient and emergency room visits (14). More than $40 \%$ of ophthalmologic outpatient visits are diagnosed with conjunctivitis annually, according to data from the Bureau of Taiwan National Health Insurance. Conjunctival disorders induced by air pollution can be subclinical ocular surface changes (12), but on many occasions with serious discomforts such as burning and irritation require clinical visits. Furthermore, chronic exposure to air pollution can induce cellular change, such as goblet-cell hyperplasia in the ocular surface (10). The discomforts of ocular diseases manifested in burning, irritation, itching, and tearing interfere with people's daily activities, including work efficiency and road safety. Treating ocular diseases by steroid eye drops occasionally results in cataracts, glaucoma, and other severe side effects, which can lead to permanent vision loss (11).

Bourcier, Viboud, Cohen, Thomas, Bury, Cadiot, Mestre, Flahault, Borderie, and Laroche investigated short-term associations between ophthalmologic emergency room visits and air pollution in Paris, and they concluded a relation between $\mathrm{NO}_{2}, \mathrm{O}_{3}, \mathrm{SO}_{2}$, and $\mathrm{PM}_{10}$ and conjunctivitis (9). Chang, Yang, Chang, and Tsai investigates the relationship between air pollution and outpatient visits for nonspecific conjunctivitis in Taiwan, and they found that the air pollutants, $\mathrm{NO}_{2}, \mathrm{SO}_{2}, \mathrm{O}_{3}$, and $\mathrm{PM}_{10}$ increase the chances of outpatient visits for nonspecific conjunctivitis and have no evident lag effects (12). Mimura, Ichinose, Yamagami, Fujishima, Kamei, Goto, Takada, and Matsubara examined the association of airborne pollutants with allergic conjunctivitis in Tokyo. Their findings suggest a possible role of $\mathrm{PM}_{2.5}$ in the development of allergic conjunctivitis during the non-pollen season. This association between $\mathrm{PM}_{2.5}$ and allergic conjunctivitis may have broad public health implications in relation to allergic diseases (13). Szyszkowicz, Kousha, and Castner examine the associations between emergency department visits for conjunctivitis and ambient air pollution levels in urban regions across the province of Ontario, Canada and they suggest that there are associations between these two, with different temporal trends (14). Based on the database of the Shanghai Health Insurance System (SHIS), Hong, Zhong, Li, Xu, Ye, $\mathrm{Mu}, \mathrm{Lu}$, Mashaghi, Zhou, Tan, Li, Sun, Liu, and Xu assess the relationship between air pollutants with outpatient visits for allergic conjunctivitis. They found that higher levels of ambient $\mathrm{NO}_{2}, \mathrm{O}_{3}$, and temperature increase the chances of outpatient visits for allergic conjunctivitis. Ambient air pollution may contribute to the worsening of allergic conjunctivitis. (15).

Most studies claimed that air pollutants are a determinant of nonspecific conjunctivitis. The results of previous studies about air pollutants on nonspecific conjunctivitis are shown in Table 1. It can be found that the relationship between nonspecific conjunctivitis and levels of $\mathrm{CO}$ and $\mathrm{O}_{3}$ are the same in these studies, while the results of the relationship between nonspecific conjunctivitis and levels of $\mathrm{NO}_{2}, \mathrm{SO}_{2}, \mathrm{PM}_{10}$ and $\mathrm{PM}_{2.5}$ are different.

Most of the data, such as air pollutants and climatic data are range-type data. Because of the limitation of traditional statistics (e.g., regression analysis), range-type data is difficult to be analyzed. Most of them are analyzed by minimum / maximum value $(9)$, mean value $(12,13,15)$, and cumulative value. Most studies developed linear regression model $(12,13,15)$ or negative binomial regression model $(14)$ using average over the period for the relationship between nonspecific conjunctivitis incidence and air pollutants data.

Many studies indicate that the maximum, minimum, or cumulative values are better than the mean value in the studies that discuss range-type data $(9,16,17)$. For example, the major drawback of the traditional statistical methods is that when the result between outcomes and each of the above-mentioned value (maximum, minimum, or cumulative) is not consistent, it will be difficult to draw a conclusion $(9,16,17)$. For example, Bourcier, Viboud, Cohen, Thomas, Bury, Cadiot, Mestre, Flahault, Borderie, and Laroche's study indicate that the maximum temperature of the day was associated with conjunctivitis and other ocular surface diseases, but minimum temperature of the day was not associated with conjunctivitis. Therefore, it is difficult to explain the relationship between conjunctivitis and temperature.

With the advent of information technology, very large datasets have become common. Traditional statistical methods do not have the power or flexibility to analyze these data efficiently and extract the required knowledge. Symbolic data 


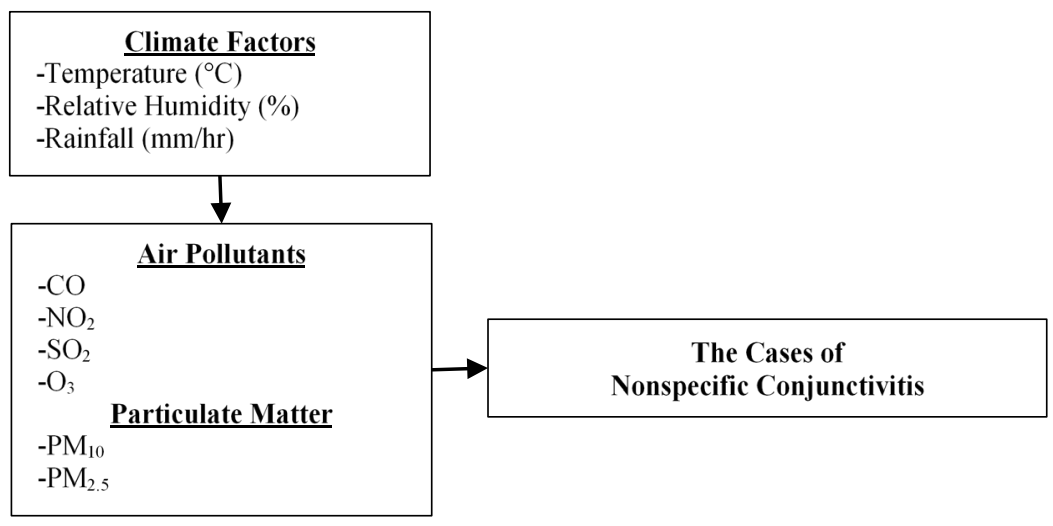

Figure 1: The research framework

analysis is to summarize a large dataset in such a way that the resulting summary dataset is of a manageable size and yet retains as much of the knowledge in the original dataset as possible $(18,19)$. One consequence of this is that the data may no longer be formatted as single values, but be represented by lists, intervals, distributions, etc. The summarized data have their own internal structure, which must be taken into account in any analysis.

Ambient air pollution may contribute to the worsening of allergic conjunctivitis (15). Air pollution is the risk factor that can be controlled by government. With governmental intervention, decreasing the morbidity of conjunctivitis will be more effective. Conjunctivitis costs one third of the annual ophthalmic pay from National Health Insurance, $2 \%$ of the annual total cost of National Health Insurance (12). If nonspecific conjunctivitis can be diminished by the control of air pollutant, it can reduce the cost of national health insurance. Therefore, one of the aims of this study is to investigate the relationship between air pollutants and the non-specific conjunctivitis in Taiwan with symbolic data analysis and to compare the different effects of air pollutants on the incidence of non-specific conjunctivitis in Taiwan.

Further, research is also needed on the association between weather and air pollutants in order to indicate air pollution and their linkage with the cases of nonspecific conjunctivitis (9). Such studies would help to determine the effects of air pollutants on the eye. Therefore, the other goal of this study is to determine the effects of climate factors on air pollutants.

\section{MATERIALS AND METHODS}

This study used symbolic data analysis to investigate the relationship between air pollution concentrations and outpatient visits for nonspecific conjunctivitis as well as the relationship between climate factors between air pollution concentrations and particulate matter (PM) (Figure 1). In the regression analysis of the cases of nonspecific conjunctivitis, the $\mathrm{CO}, \mathrm{NO}_{2}, \mathrm{SO}_{2}, \mathrm{O}_{3}, \mathrm{PM}_{10}$, and $\mathrm{PM}_{2.5}$ are regarded as air pollutants. And in the regression analysis of these 6 air pollutants, temperature, relative humidity, and rainfall are considered as climatic factors.

\section{Study Area}

Taipei city is in the northern part of Taiwan. It is the largest city and the capital city of Taiwan. The city is home to an estimated population of 2,689,845 in 2017. Taipei city has excellent capabilities for managing air quality, and it keeps high quality data of air pollutants. Therefore, this study focuses on Taipei city as the target area for investigation. The city's rainy climate, location near the coast, and strong environmental regulations have prevented air pollution from becoming a substantial health issue. However, smog is still extremely common and the visibility throughout the city is not good during rain-less days.

Taiwan has made efforts on air pollution monitoring and control. The Environmental Protection Administration (EPA) of Taiwan started to set up the Taiwan Air Quality Monitoring Network (TAQMN) in 1990. In September 1993, there were 66 air quality monitoring stations in TAQMN, replacing the original 19. Up until 1998, there were 72 air quality monitoring stations, including four traffic pattern stations, four background pattern stations, three industrial pattern stations and two national park pattern stations. These five types of air quality monitoring stations serve different purposes.

In Taiwan, the priority pollutants that can be monitored through continuous emission monitoring systems (CEMS) of the monitoring network include sulfur dioxides $\left(\mathrm{SO}_{2}\right)$, carbon monoxide $(\mathrm{CO})$, ozone $\left(\mathrm{O}_{3}\right)$, particulate matter $\left(\mathrm{PM}_{10}\right.$ and $\left.\mathrm{PM}_{2.5}\right)$, nitrogen oxides $\left(\mathrm{NO}_{\mathrm{x}}\right)$, and hydrocarbons $\left(\mathrm{HC}_{\mathrm{s}}\right)$. 


\section{Data Collection}

The research focuses on the significance of air pollution's impact on ocular health. Data for ophthalmology outpatient visits were obtained from the National Health Insurance Research Database of Taiwan. Nonspecific conjunctivitis was defined and filtered according to the diagnostic codes in the International Classification of Diseases, 9th revision (ICD9). Ambient air monitoring data were obtained from the Taiwan Environmental Protection Administration air pollution monitoring stations. Six regulated air pollutants were included in this study.

\section{Air pollutant concentrations data and climate data}

The Taiwan Environmental Protection Administration (EPA) began to establish Taiwan Air Quality Monitoring Network (TAQMN) in 1990. The monitoring stations are divided into 5 categories in this network by the characteristics of pollutants, geometrical and meteorological conditions, population distribution and traffic conditions. These 5 categories include ambient stations, traffic air monitoring stations, industrial stations, national park air monitoring stations, and background air monitoring stations.

Though many air pollutants and climatic factors are monitored in Taiwan, not every air monitoring station monitors all kinds of the air pollutants because different kind of monitoring stations has its own purpose. This study only concerns about $\mathrm{CO}, \mathrm{NO}_{2}, \mathrm{SO}_{2}, \mathrm{O}_{3}, \mathrm{PM}_{10}$ and $\mathrm{PM}_{2.5}$. These air pollutants are regarded as criteria pollutants because the pollutant standard index (PSI) is based on them. Only the monitoring stations that contained data with all these six pollutants were considered for this study.

The study used daily ambient air-quality data between 2003 and 2010 that were extracted from the database maintained by the EPA. TAQMN divides Taiwan into seven air-quality control areas: North, Chu-Miao, Central, Yun-ChiaNan, Kao-Ping, Yilan, and Hua-Tung. There are 70 fully automatic monitoring stations measuring air quality in these areas. Air pollutants considered in the analysis were particulate matter $\left(\mathrm{PM}_{10}\right.$ and $\left.\mathrm{PM}_{2.5}\right)$, nitrogen dioxide $\left(\mathrm{NO}_{2}\right)$, sulfur dioxide $\left(\mathrm{SO}_{2}\right)$, ozone $\left(\mathrm{O}_{3}\right)$, and carbon monoxide $(\mathrm{CO})$. $\mathrm{CO}$ was analyzed by the infrared method; $\mathrm{NO}_{2}$ by the chemiluminescence method; $\mathrm{SO}_{2}$ by the ultraviolet fluorescence method; $\mathrm{O}_{3}$ by the ultraviolet absorption method, and $\mathrm{PM}_{10}$ and $\mathrm{PM}_{2.5}$ by the beta-ray attenuation method. Temperature, rainfall, and relative humidity data were concurrently obtained from this database.

\section{Patient visits data}

The clinic visit counts of non-specific conjunctivitis were obtained from the data of National Health Insurance database. This database is originated from the Bureau of National Health Insurance (BNHI) and cleaned by National Health Research Institute (NHRI) of Taiwan. Over $97 \%$ of Taiwan's population is insured by National Health Insurance; therefore, this database is considered representative of health system use in Taiwan. The NHRI has collected health data from BNHI since 1997 and published the annual data every year. Due to the difficulties involved in managing such large amount of data, decision was previously made to randomly sample information on 1 out of 500 clinic visits, which were then cleaned and publicized without personal information for research use.

Data from ophthalmologic outpatient visits between 2003 and 2010 were obtained from the National Health Insurance Database. In ICD-9-CM, acute conjunctivitis is coded 372.00; chronic conjunctivitis is coded 372.10; simple chronic conjunctivitis is coded 372.11; other chronic allergic conjunctivitis is coded 372.14; blepharoconjunctivitis is coded 372.20, other and unspecified conjunctivitis is coded 372.30; and conjunctival hemorrhage is coded 372.72 . To protect privacy, the data on patient identities and institutions had been scrambled cryptographically.

\section{Symbolic Data Analysis}

Symbolic data analysis is a relatively new field that provides a range of methods for analyzing complex datasets. Traditional statistical methods do not have the power or flexibility to make sense of very large datasets, and symbolic data analysis techniques can be developed in order to extract knowledge from such data. The analysis of symbolic data differs from that of the traditional. Rather than identifying points of interest in the data, symbolic data methods allow the user to build models of the data and make predictions about future events (20).

The cases of nonspecific conjunctivitis of Taipei from November 2003 to December 2010 were analyzed with symbolic linear regression analysis for interval-valued data with R 3.4.1 with SparkR 2.0.1 in symbolic data analysis with centermethod $(21,22)$. The regression model plots the nonspecific conjunctivitis incidence (cases) versus $\mathrm{CO}_{1} \mathrm{NO}_{2}, \mathrm{SO}_{2}$, and $\mathrm{O}_{3}$ in the following equation: 
The regression model plots the nonspecific conjunctivitis incidence (cases) versus $\mathrm{PM}_{10}$, and $\mathrm{PM}_{2.5}$ in the following equation:

nonspecific conjunctivitis incidence $=\beta_{0}+\beta_{1} * \mathrm{PM}_{10}+\beta_{2} * \mathrm{PM} 2.5$

The regression model plots the air pollutants $\left(\mathrm{CO}, \mathrm{NO}_{2}, \mathrm{SO}_{2}, \mathrm{O}_{3}, \mathrm{PM}_{10}\right)$ versus temperature $\left({ }^{\circ} \mathrm{C}\right)$, relative humidity $(\%)$, rainfall $(\mathrm{mm} / \mathrm{hr})$ in the following equation:

The Level of $\mathrm{CO}=\beta_{0}+\beta_{1}{ }^{*}$ temperature $+\beta_{2}{ }^{*}$ relative humidity $+\beta_{3}{ }^{*}$ rainfall

The Level of $\mathrm{NO}_{2}=\beta_{0}+\beta_{1}{ }^{*}$ temperature $+\beta_{2}{ }^{*}$ relative humidity $+\beta_{3}{ }^{*}$ rainfall

The Level of $\mathrm{SO}_{2}=\beta_{0}+\beta_{1}{ }^{*}$ temperature $+\beta_{2}{ }^{*}$ relative humidity $+\beta_{3}{ }^{*}$ rainfall

The Level of $\mathrm{O}_{3}=\beta_{0}+\beta_{1}{ }^{*}$ temperature $+\beta_{2}{ }^{*}$ relative humidity $+\beta_{3}{ }^{*}$ rainfall

The Level of $P M_{10}=\beta_{0}+\beta_{1}{ }^{*}$ temperature $+\beta_{2}{ }^{*}$ relative humidity $+\beta_{3}{ }^{*}$ rainfall

The Level of $P M_{2.5}=\beta_{0}+\beta_{1}{ }^{*}$ temperature $+\beta_{2}{ }^{*}$ relative humidity $+\beta_{3}{ }^{*}$ rainfall

Billard and Diday proposed an approach for a constrained linear regression model on the midpoints and range of the interval values (18). The prediction of the lower and upper boundaries of the interval value of the dependent variable is accomplished from its midpoint and range, which are estimated from the fitted linear regression models applied to the midpoint and range of each interval value of the independent variables.

Based on Billard and Diday's study, the estimate of the parameters $\beta$ is based only on the midpoint of the intervals according to the criterion considered. Let $E=\{e 1, \ldots, e n\}$ be a set of examples that are described by $p+1$ interval-valued variables $Y, X_{1}, \ldots, X_{p}$. Each example is represented as an interval quantitative feature vector $z_{i}=\left(x_{i}, y_{i}\right), x i=\left(x_{i 1}, \ldots, x_{i p}\right)$, where $x_{i j}=\left[a_{i j}, b_{i j}\right] \in \hat{s}=\{[a]:, a, b \in R, a \leq b\}(\mathrm{j}=1, \ldots, \mathrm{p})$ and $y_{i}=\left[y_{L i}, y_{U i}\right] \in \hat{s}$ are, respectively, the observed values of $\mathrm{X}_{\mathrm{j}}$ and $\mathrm{Y}$.

It can be considered that $X_{1}, \ldots, X_{p}$ related to $Y$ according to the linear regression relationship:

$$
\begin{aligned}
& y_{L i}=\beta_{0}+\beta_{1} a_{i 1}+\cdots+\beta_{p} a_{i p}+\varepsilon_{L i} \\
& y_{U i}=\beta_{0}+\beta_{1} b_{i 1}+\cdots+\beta_{p} b_{i p}+\varepsilon_{U i}
\end{aligned}
$$

From equation (2), the sum of the squares of deviations in this first approach is as follows:

$$
S_{c m}=\sum_{i=1}^{n}\left(\epsilon_{L i}+\epsilon_{U i}\right)^{2}=\sum_{i=1}^{n}\left(y_{L i}-\beta_{0}-\beta_{1} \alpha_{i 1}-\cdots \beta_{p} \alpha_{i p}+y_{U i}-\beta_{0}-\beta_{1} b_{i 1}-\cdots \beta_{p} b_{i p}\right)^{2}
$$

which represents the sum of the square of the sum of the lower and upper boundary errors.

Lima Neto and de Carvalho present the estimates of the vector of parameters $\beta$ in matrix notation for the center method (22), which can be rewritten in the simplest form as

$$
y^{C}=X^{C} \beta+\varepsilon^{C}
$$

where

$$
\begin{gathered}
y^{C}=\left(y_{1}^{C}, \cdots y_{n}^{C}\right)^{T} \\
\left.X^{C}=\left(x_{1}^{C}\right)^{T}, \cdots\left(x_{n}^{C}\right)^{T}\right)^{T} \\
\left(x_{i}^{C}\right)^{T}=\left(1, x_{i 1}^{C}, \ldots x_{i p}^{C}\right), i=1, \cdots, n \\
\beta=\left(\beta_{0}, \cdots, \beta_{p}\right)^{T} \\
\varepsilon^{C}=\left(\varepsilon_{1}^{C}, \ldots, \varepsilon_{n}^{C}\right)^{T}
\end{gathered}
$$

If $X_{c}$ has full rank $(p+1) \leqq n$, the least square estimate of $\beta$ in equation (8) is given by

$$
\hat{\beta}=\left(\left(X^{C}\right)^{T} X^{C}\right)^{-1}\left(X^{C}\right)^{T} y^{C}
$$

Given a new example e, described by $z=(x, y)$, where $x=\left(x_{1}, \ldots, x_{p}\right)$ with $x_{j}=\left[a_{i}, b_{j}\right](j=1, \ldots, p)$, the value $y=[y, y u$ of $Y$ will be predicted by as follows:

where

$$
\begin{aligned}
& \hat{y}_{L}=\left(x_{L}\right)^{T} \hat{\beta} \\
& \hat{y}_{U}=\left(x_{U}\right)^{T} \hat{\beta}
\end{aligned}
$$

$$
\begin{aligned}
& \left(x_{L}\right)^{T}=\left(1, a_{1}, \cdots, a_{p}\right) \\
& \left(x_{U}\right)^{T}=\left(1, b_{1}, \cdots, b_{p}\right)
\end{aligned}
$$

The determination coefficient $\left(R^{2}\right)$ represents a goodness-of-fit measure commonly used in regression analysis to capture the adjustment quality of a model. The determination coefficient $\left(R^{2}\right)$ for the $C M$ method is easily established as

$$
R_{c m}^{2}=\frac{\sum_{i=1}^{n}\left(\hat{y}_{i}^{C}-\bar{y}^{C}\right)^{2}}{\sum_{i=1}^{n}\left(y_{i}^{C}-\bar{y}^{C}\right)^{2}}
$$

However, note that $y^{C}=\left(y_{L}+y_{U}\right)$. Thus, the equation (14) can be replaced by

$$
R_{c m}^{2}=\frac{\sum_{i=1}^{n}\left(\left(\hat{y}_{L i}+\hat{y}_{U i}\right)-\left(\bar{y}_{L i}+\bar{y}_{U i}\right)\right)^{2}}{\sum_{i=1}^{n}\left(\left(y_{L i}+y_{U i}\right)-\left(\bar{y}_{L i}+\bar{y}_{U i}\right)\right)^{2}}
$$


Table 2: The characteristics of the research data in the cases of nonspecific conjunctivitis

\begin{tabular}{|c|c|c|c|c|c|}
\hline & $\begin{array}{c}\text { Total } \\
\text { (Year) }\end{array}$ & $\begin{array}{c}\text { Mean } \\
\text { (Monthly) }\end{array}$ & $\begin{array}{c}\text { S.E. } \\
\text { (Monthly) }\end{array}$ & $\begin{array}{c}\text { Min } \\
\text { (Monthly) }\end{array}$ & $\begin{array}{c}\text { Max } \\
\text { (Monthly) }\end{array}$ \\
\hline 2003/Nov. 2003/Dec. & 254,414 & $127,207.00$ & $30,467.82$ & 105,663 & 148,751 \\
\hline 2004/Jan. 2004/Dec. & $2,547,761$ & $212,313.42$ & $120,080.38$ & 74,242 & 430,065 \\
\hline 2005/Jan. 2005/Dec. & $8,757,736$ & $729,811.33$ & $287,806.09$ & 235,733 & $1,062,046$ \\
\hline 2006/Jan. 2006/Dec. & $11,584,004$ & $965,333.67$ & $153,346.36$ & 679,133 & $1,105,426$ \\
\hline 2007/Jan. 2007/Dec. & $11,721,826$ & $976,818.83$ & $190,714.96$ & 557,177 & $1,370,092$ \\
\hline 2008/Jan. 2008/Dec. & $10,795,315$ & $899,609.58$ & $160,211.80$ & 706,190 & $1,213,140$ \\
\hline 2009/Jan. 2009/Dec. & $12,210,401$ & $1,017,533.42$ & $98,481.57$ & 785,554 & $1,166,525$ \\
\hline 2010/Jan. 2010/Dec. & $12,769,697$ & $1,064,141.42$ & $123,629.30$ & 812,276 & $1,264,924$ \\
\hline
\end{tabular}

Table 3: The characteristics of the research data in daily climatic data

\begin{tabular}{cccc}
\hline & Temperature $\left({ }^{\circ} \mathbf{C}\right)$ & Relative Humidity (\%) & Rainfall (mm/hr) \\
\hline & U[lower, upper] & U[lower, upper] & U[lower, upper] \\
\hline 2003/Nov. 2003/Dec. & $\mathrm{U}[12.19,28.77]$ & $\mathrm{U}[5.19,92.90]$ & $\mathrm{U}[0,3.20]$ \\
\hline 2004/Jan. 2004/Dec. & $\mathrm{U}[7.75,39.36]$ & $\mathrm{U}[28.98,94.37]$ & $\mathrm{U}[0,64.60]$ \\
\hline 2005/Jan. $~ 2005 /$ Dec. & $\mathrm{U}[0.71,37.04]$ & $\mathrm{U}[25.46,100.00]$ & $\mathrm{U}[0,56.00]$ \\
\hline 2006/Jan. 2006/Dec. & $\mathrm{U}[0.67,41.99]$ & $\mathrm{U}[13.19,100.00]$ & $\mathrm{U}[0,49.00]$ \\
\hline 2007/Jan. $~ 2007 /$ Dec. & $\mathrm{U}[0.05,39.41]$ & $\mathrm{U}[10.84,100.00]$ & $\mathrm{U}[0,73.00]$ \\
\hline 2008/Jan. $\sim$ 2008/Dec. & $\mathrm{U}[0.70,38.35]$ & $\mathrm{U}[8.69,99.99]$ & $\mathrm{U}[0,69.60]$ \\
\hline 2009/Jan. $~ 2009 /$ Dec. & $\mathrm{U}[2.05,43.73]$ & $\mathrm{U}[8.62,99.43]$ & $\mathrm{U}[0,81.40]$ \\
\hline
\end{tabular}

Billard and Diday's method (18) indicate the importance of range-type information in prediction performance as well as the application of inequality constraints to ensure mathematical coherence between the predicted values of the lower and upper boundaries of the interval-value data.

\section{RESULTS}

Using monthly aggregated data, outpatient visit data of nonspecific conjunctivitis of Taipei from 2003 to 2010 were analyzed with symbolic linear regression analysis for the interval-valued data in this study. The climatic data in this study includes temperature $\left({ }^{\circ} \mathrm{C}\right)$, relative humidity (\%), and rainfall (hours). The air pollutants data in this study includes $\mathrm{CO}$, $\mathrm{NO}_{2}, \mathrm{SO}_{2}, \mathrm{O}_{3}, \mathrm{PM}_{10}$ and $\mathrm{PM}_{2.5}$ The type of these data is interval-valued data, and they all can be presented as U[lower, upper], meaning the range of the data is from minimum (lower) to maximum (upper). Details of the non-specific conjunctivitis incidence in Taipei, climate factors, $\mathrm{CO}, \mathrm{NO}_{2}, \mathrm{SO}_{2}$, and $\mathrm{O}_{3}$ measurements and PM are presented in Table 2, Table 3, Table 4, and Table 5 respectively.

For the 86-month period (November 2003 December 2010), the number of non-specific conjunctivitis cases in Taipei was from 74,242 to 1,370,092, with the highest occurred in October 2007 and the lowest occurred in April 2004 (Table 2).

The characteristics of the daily climatic data is in Table 3. The daily minimum temperature was from $-0.54^{\circ} \mathrm{C}$ to $25.77^{\circ} \mathrm{C}$, with the lowest recorded minimum temperature in March 2010. The daily maximum temperature was from $23.85^{\circ} \mathrm{C}$ to $43.73^{\circ} \mathrm{C}$, with the highest recorded daily temperature in June 2009 . The daily minimum relative humidity was from $5.19 \%$ to $50.61 \%$, with the lowest in November 2003 . The monthly maximum relative humidity was from $85.12 \%$ to $100.00 \%$. The daily rainfall was from 0 to $81.40 \mathrm{~mm} / \mathrm{hr}$, with the maximum recorded daily rainfall in August 2009 .

The daily air pollutants data is shown in Table 4. The maximum daily CO was from $2.00 \mathrm{ppb}$ to $6.52 \mathrm{ppb}$, with the maximum recorded in February 2005. The maximum daily $\mathrm{NO}_{2}$ was from $56.37 \mathrm{ppb}$ to $139.63 \mathrm{ppb}$, with the maximum recorded in February 2005. The maximum daily $\mathrm{SO}_{2}$ was from $10.2 \mathrm{ppb}$ to $68.4 \mathrm{ppb}$, with the maximum recorded in August 2010. The maximum daily $\mathrm{O}_{3}$ was from $43.2 \mathrm{ppb}$ to $221.5 \mathrm{ppb}$, with the maximum recorded in May 2007. 
Table 4: The characteristics of the research data in daily air pollutants data

\begin{tabular}{|c|c|c|c|c|}
\hline & CO (ppb) & $\mathrm{NO}_{2}$ (ppb) & $\mathrm{SO}_{2}(\mathrm{ppb})$ & $\mathrm{O}_{3}$ (ppb) \\
\hline & U[lower, upper] & U[lower, upper] & U[lower, upper] & U[lower, upper] \\
\hline 2003/Nov. 2003/Dec. & $\mathrm{U}[0.01,3.63]$ & $U[2.18,85.48]$ & $U[0.1,27.6]$ & $U[0.1,114.2]$ \\
\hline 2004/Jan. 2004/Dec. & $\mathrm{U}[0.01,3.96]$ & $U[0.82,129.34]$ & $U[0.1,35.7]$ & $U[0.1,184.9]$ \\
\hline 2005/Jan. 2005/Dec. & $\mathrm{U}[0.01,6.52]$ & $U[0.02,139.63]$ & $U[0.1,62.6]$ & $\mathrm{U}[0.1,175.4]$ \\
\hline 2006/Jan. 2006/Dec. & $U[0.01,5.38]$ & $U[0.02,131.91]$ & $\cup[0.1,58.9]$ & $U[0.1,160.7]$ \\
\hline 2007/Jan. 2007/Dec. & $\mathrm{U}[0.05,4.92]$ & $U[0.01,135.42]$ & $U[0.1,54.3]$ & $\mathrm{U}[0.1,221.5]$ \\
\hline 2008/Jan. 2008/Dec. & $\mathrm{U}[0.02,4.66]$ & $U[0.01,124.39]$ & $U[0.1,46.8]$ & $U[0.1,155.3]$ \\
\hline 2009/Jan. 2009/Dec. & $\mathrm{U}[0.05,4.83]$ & $U[0.01,117.52]$ & $U[0.1,52.5]$ & $U[0.1,149.5]$ \\
\hline
\end{tabular}

Table 5: The characteristics of the research data in daily particulate matter data

\begin{tabular}{ccc}
\hline & PM $_{\mathbf{1 0}}(\mathbf{m g} \times \mathbf{m}-\mathbf{3})$ & $\mathbf{P M}_{\mathbf{2 . 5}}$ (mg $\left.\times \mathbf{m}-\mathbf{3}\right)$ \\
\hline & U[lower, upper] & U[lower, upper] \\
\hline 2003/Oct. 2003/Dec. & $\mathrm{U}[8,215]$ & $\mathrm{U}[2.35,147.71]$ \\
\hline 2004/Jan. 2004/Dec. & $\mathrm{U}[2,219]$ & $\mathrm{U}[1.00,141.00]$ \\
\hline 2005/Jan. 2005/Dec. & $\mathrm{U}[1,279]$ & $\mathrm{U}[1.00,130.00]$ \\
\hline 2006/Jan. 2006/Dec. & $\mathrm{U}[1,414]$ & $\mathrm{U}[1.00,237.00]$ \\
\hline 2007/Jan. 2007/Dec. & $\mathrm{U}[1,416]$ & $\mathrm{U}[1.00,170.00]$ \\
\hline 2008/Jan. 2008/Dec. & $\mathrm{U}[1,310]$ & $\mathrm{U}[1.00,176.00]$ \\
\hline 2009/Jan. 2009/Dec. & $\mathrm{U}[1,1088]$ & $\mathrm{U}[1.00,167.00]$ \\
\hline
\end{tabular}

The characteristics of the research data of daily particulate matter data is in Table 5. The maximum daily $\mathrm{PM}_{10}$ was

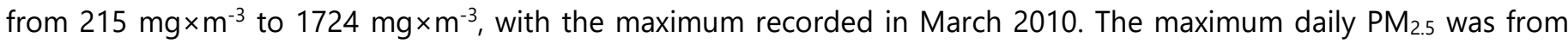

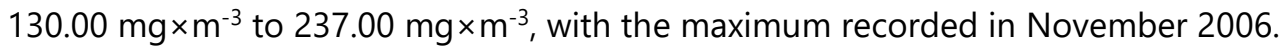

\section{The Relationship between Climate Factors and Air Pollutants}

The relationship between climate factors and air pollutants by confirmatory factor analysis (CFA) symbolic scatter is plotted in Figure 2 and Figure 3. The predictive model plots nonspecific conjunctivitis incidence versus temperature $\left({ }^{\circ} \mathrm{C}\right)$, relative humidity $(\%)$, rainfall $(\mathrm{mm} / \mathrm{hr})$ in Equation (3) (8).

The results demonstrate that climatic factors are associated with air pollutants (Table 6): First, daily temperature (tvalue $=-2.809, p$-value $=0.006$ ) is negatively correlated with $\mathrm{CO}$. The relationship between relative humidity and rainfall with $\mathrm{CO}$ is not statistical significance, and this is the same as plot (a) in Figure 2. Second, the relationship between daily temperature / relative humidity / rainfall and $\mathrm{NO}_{2}$ is not statistically significant. Third, daily rainfall (t-value $=2.567, \mathrm{p}-$ value $=0.012$ ) is positively correlated with $\mathrm{SO}_{2}$, and this is consistent with plot (i) in Figure 2 . The relationship between temperature / relative humidity and $\mathrm{CO}$ is not statistically significant. Last, daily temperature ( $\mathrm{t}-\mathrm{value}=4.645, \mathrm{p}$ value $<0.001$ ) is negatively correlated with $\mathrm{O}_{3}$, and this is the same as plot (j) in Figure $\mathbf{2}$. The relationship between relative humidity / rainfall and $\mathrm{O}_{3}$ is not statistically significant. 


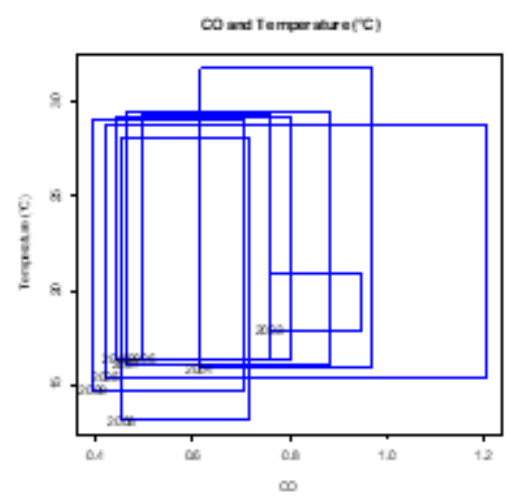

(a) $\mathrm{CO}$ with Temperature $\left({ }^{\circ} \mathrm{C}\right)$

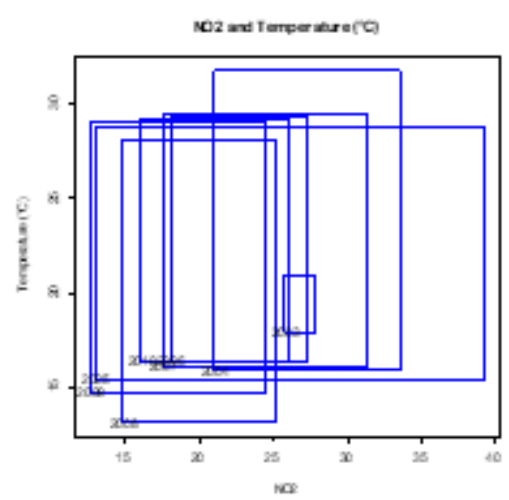

(d) NO2 with Temperature $\left({ }^{\circ} \mathrm{C}\right)$

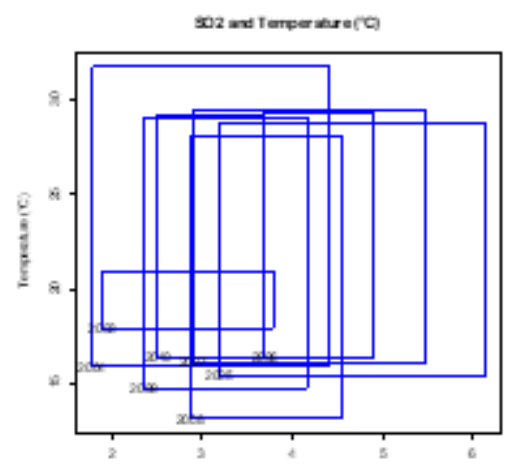

(g) $\mathrm{SO}_{2}$ with Temperature $\left({ }^{\circ} \mathrm{C}\right)$

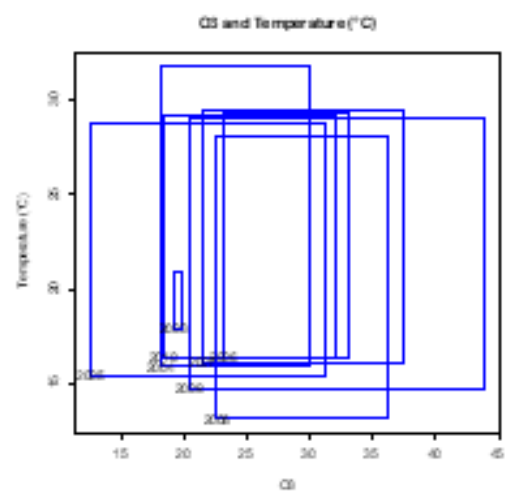

(j) $\mathrm{O} 3$ with Temperature $\left({ }^{\circ} \mathrm{C}\right)$

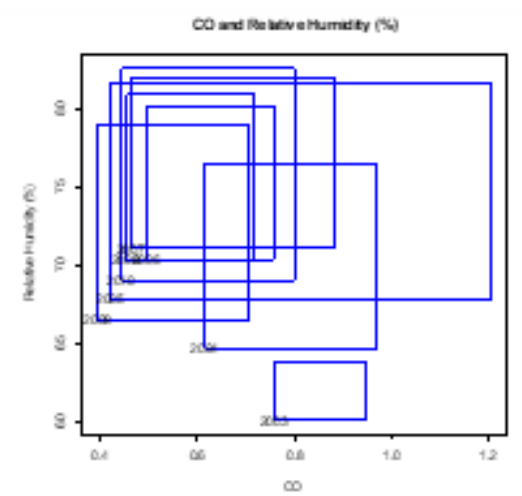

(b) $\mathrm{CO}$ with Relative Humidity (\%)

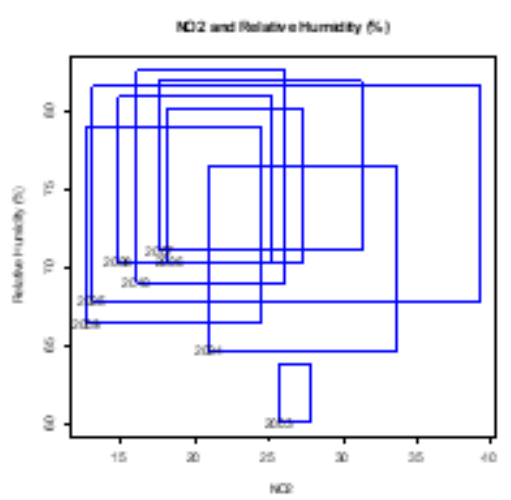

(e) NO2 with Relative Humidity

$(\%)$

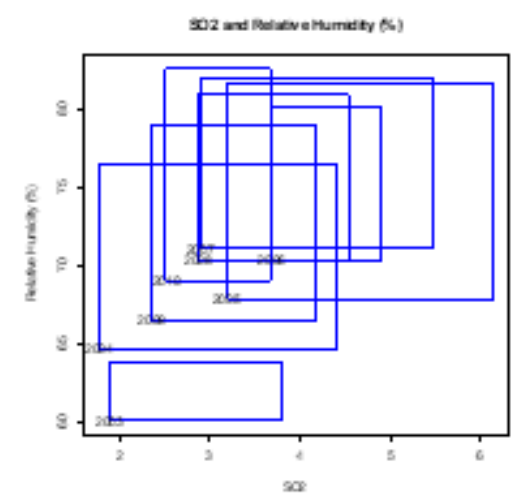

(h) $\mathrm{SO} 2$ with Relative Humidity

$(\%)$

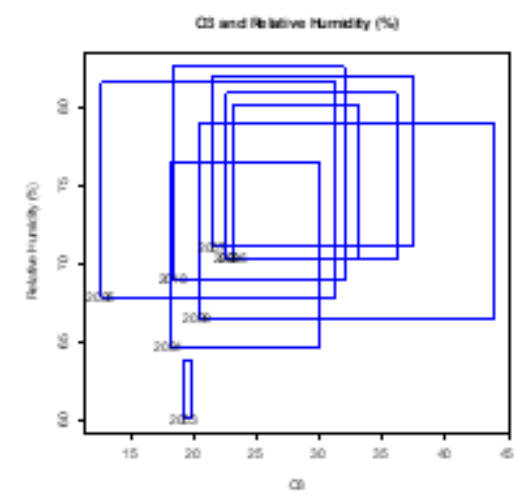

(k) $\mathrm{O} 3$ with Relative Humidity (\%)

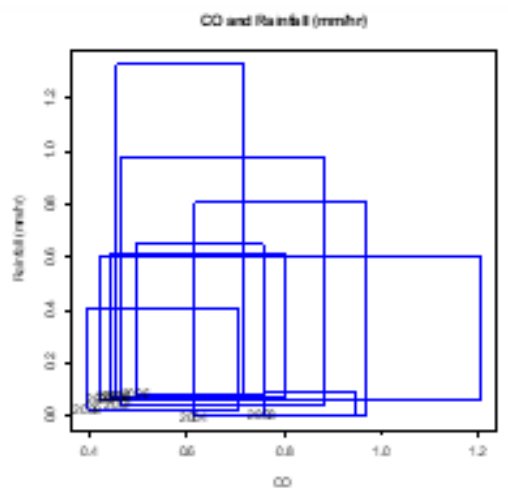

(c) $\mathrm{CO}$ with Rainfall $(\mathrm{mm} / \mathrm{hr})$

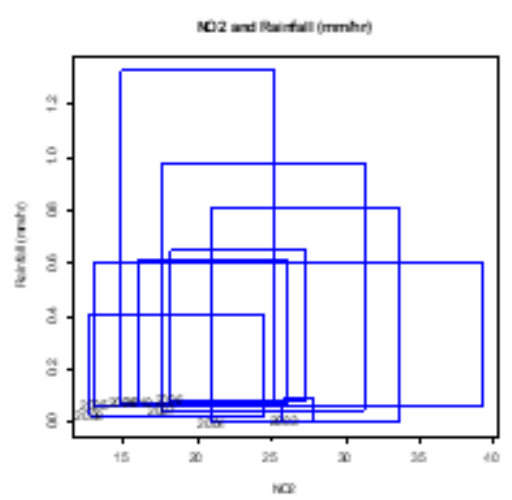

(f) NO2 with Rainfall (mm/hr)

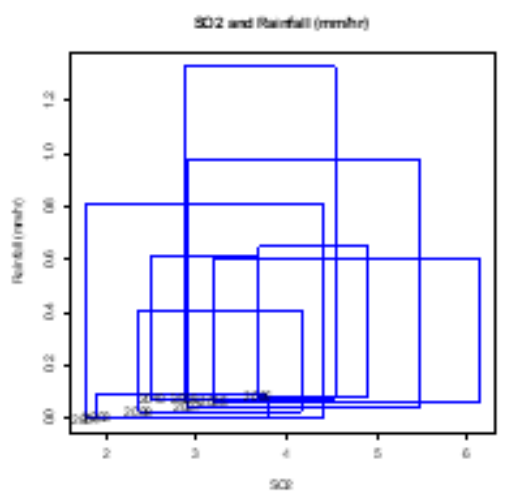

(i) $\mathrm{SO} 2$ with Rainfall $(\mathrm{mm} / \mathrm{hr})$

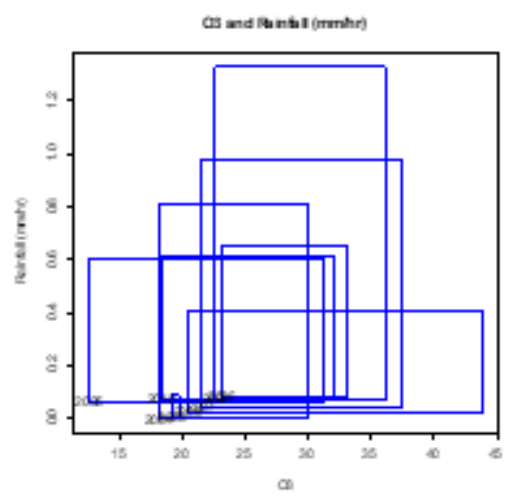

(l) $\mathrm{O} 3$ with Rainfall $(\mathrm{mm} / \mathrm{hr})$

Figure 2: Overall survival time by stage 
PMenth T iarpenasw (C)

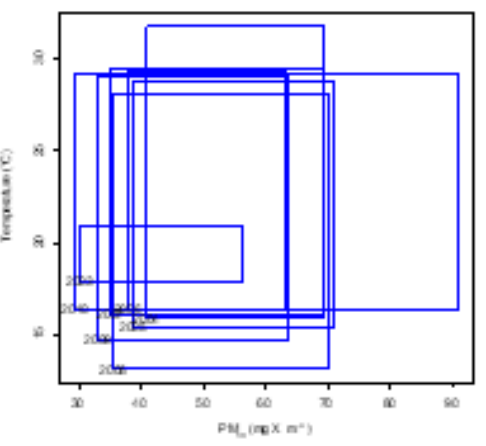

(a) PM10 with Temperature $\left({ }^{\circ} \mathrm{C}\right)$

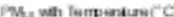

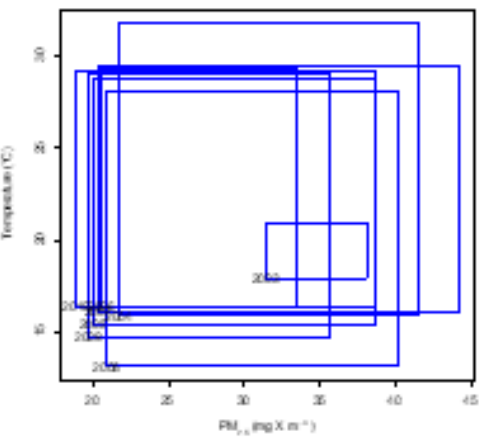

(d) PM2.5 with Temperature $\left({ }^{\circ} \mathrm{C}\right)$

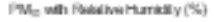

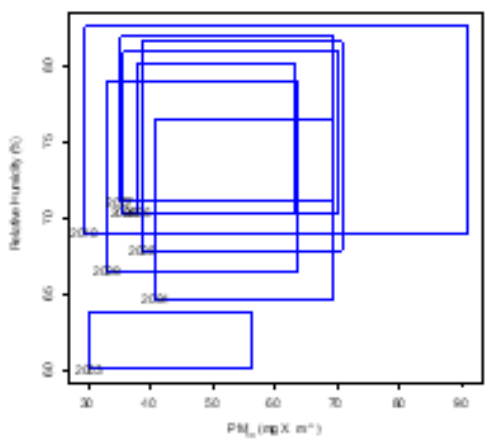

(b) PM10 with Relative Humidity

$(\%)$

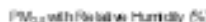

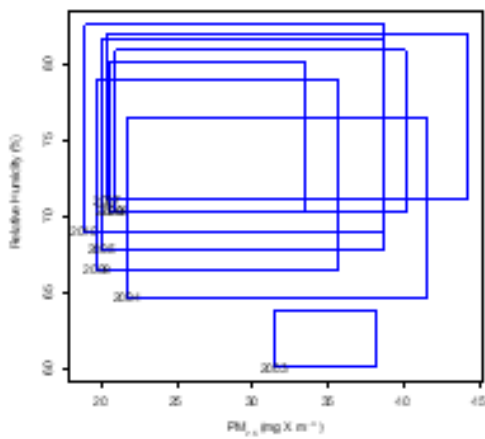

(e) PM2.5 with Relative Humidity

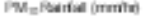

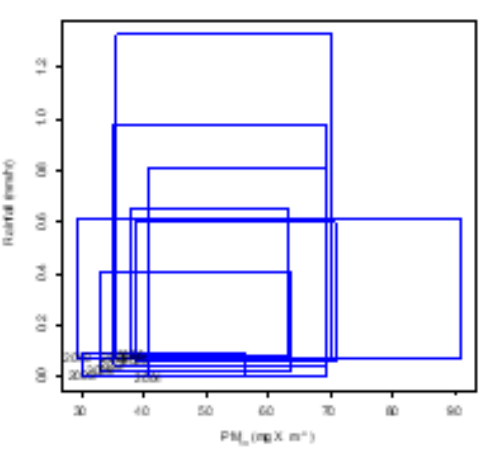

(c) PM10 with Rainfall (mm/hr)

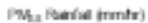

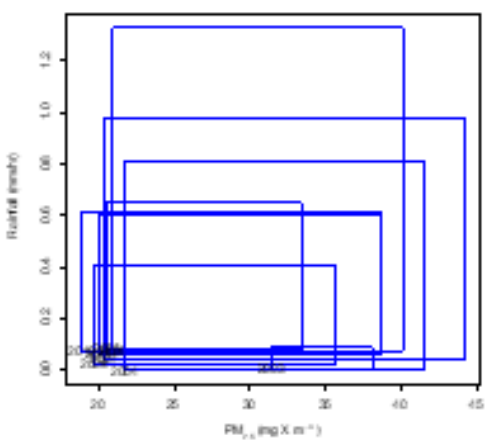

(f) PM2.5 with Rainfall (mm/hr)

(\%)

Figure 3: Overall survival time by stage

Table 6: Symbolic regression analysis of climatic factor affecting air pollutants and particulate matter incidence in Taiwan

\begin{tabular}{|c|c|c|c|c|c|c|}
\hline $\begin{array}{l}\text { Dependent } \\
\text { Variable }\end{array}$ & $\begin{array}{c}\text { Independent } \\
\text { Variable }\end{array}$ & Estimate & S.E. & t-value & p-value & $R^{2} / \operatorname{Adj}-R^{2}$ \\
\hline \multirow[t]{4}{*}{$\mathrm{CO}$} & (Intercept) & 2.747 & 0.583 & 4.711 & $<0.001$ & $0.231 / 0.203$ \\
\hline & Temperature $\left({ }^{\circ} \mathrm{C}\right)$ & -0.034 & 0.012 & -2.809 & 0.006 & \\
\hline & Relative Humidity (\%) & -0.003 & 0.008 & -0.363 & 0.717 & \\
\hline & Rainfall (mm/hr) & -0.003 & 0.006 & -0.567 & 0.572 & \\
\hline \multirow[t]{4}{*}{$\mathrm{NO}_{2}$} & (Intercept) & 83.882 & 12.854 & 6.526 & $<0.001$ & $0.299 / 0.273$ \\
\hline & Temperature $\left({ }^{\circ} \mathrm{C}\right)$ & -0.502 & 0.271 & -1.854 & 0.067 & \\
\hline & Relative Humidity (\%) & -0.357 & 0.181 & -1.967 & 0.053 & \\
\hline & Rainfall (mm/hr) & -0.237 & 0.135 & -1.753 & 0.083 & \\
\hline \multirow[t]{4}{*}{$\mathrm{SO}_{2}$} & (Intercept) & 18.224 & 7.919 & 2.301 & 0.024 & $0.129 / 0.097$ \\
\hline & Temperature $\left({ }^{\circ} \mathrm{C}\right)$ & -0.052 & 0.167 & -0.312 & 0.756 & \\
\hline & Relative Humidity (\%) & -0.081 & 0.112 & -0.724 & 0.471 & \\
\hline & Rainfall (mm/hr) & 0.214 & 0.083 & 2.567 & 0.012 & \\
\hline \multirow[t]{4}{*}{$\mathrm{O}_{3}$} & (Intercept) & 45.019 & 19.529 & 2.305 & 0.024 & $0.331 / 0.307$ \\
\hline & Temperature $\left({ }^{\circ} \mathrm{C}\right)$ & 1.910 & 0.411 & 4.645 & $<0.001$ & \\
\hline & Relative Humidity (\%) & -0.401 & 0.276 & -1.454 & 0.150 & \\
\hline & Rainfall (mm/hr) & -0.109 & 0.205 & -0.532 & 0.596 & \\
\hline \multirow[t]{4}{*}{$\mathrm{PM}_{10}$} & (Intercept) & 452.941 & 145.998 & 3.102 & 0.003 & $0.095 / 0.062$ \\
\hline & Temperature $\left({ }^{\circ} \mathrm{C}\right)$ & -4.959 & 3.075 & -1.613 & 0.111 & \\
\hline & Relative Humidity (\%) & -3.666 & 2.061 & -1.779 & 0.079 & \\
\hline & Rainfall (mm/hr) & 0.456 & 1.535 & 0.297 & 0.767 & \\
\hline \multirow[t]{4}{*}{$\mathrm{PM}_{2.5}$} & (Intercept) & 86.072 & 23.004 & 3.742 & $<0.001$ & $0.243 / 0.215$ \\
\hline & Temperature $\left({ }^{\circ} \mathrm{C}\right)$ & -0.308 & 0.485 & -0.635 & 0.527 & \\
\hline & Relative Humidity (\%) & -0.179 & 0.325 & -0.551 & 0.583 & \\
\hline & Rainfall (mm/hr) & -0.660 & 0.242 & -2.730 & 0.008 & \\
\hline
\end{tabular}


Nonspecific Conjunctivitis Cases and CO

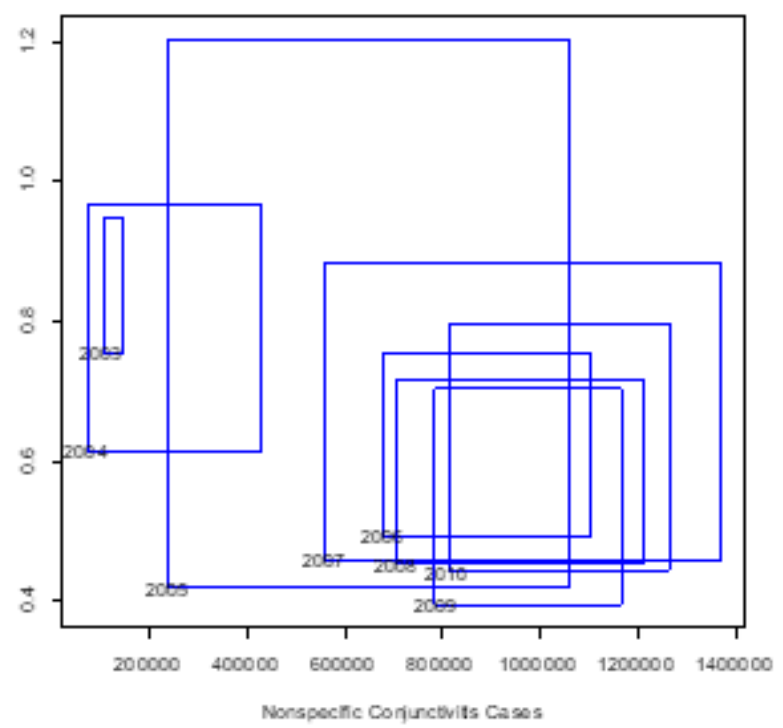

(a) Nonspecific Conjunctivitis Cases with $\mathrm{CO}$

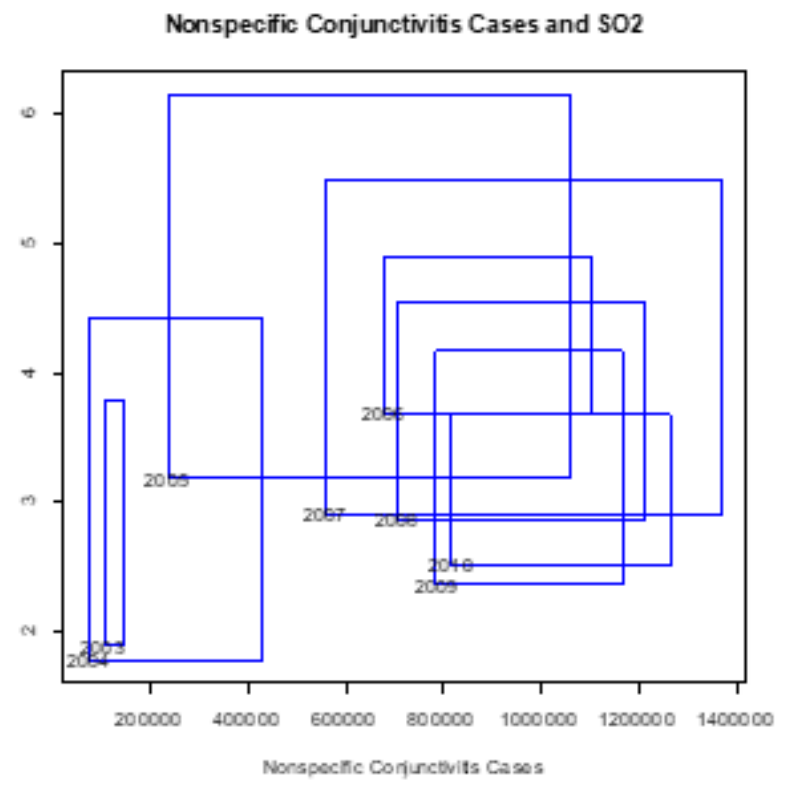

(c) Nonspecific Conjunctivitis Cases with $\mathrm{SO}_{2}$

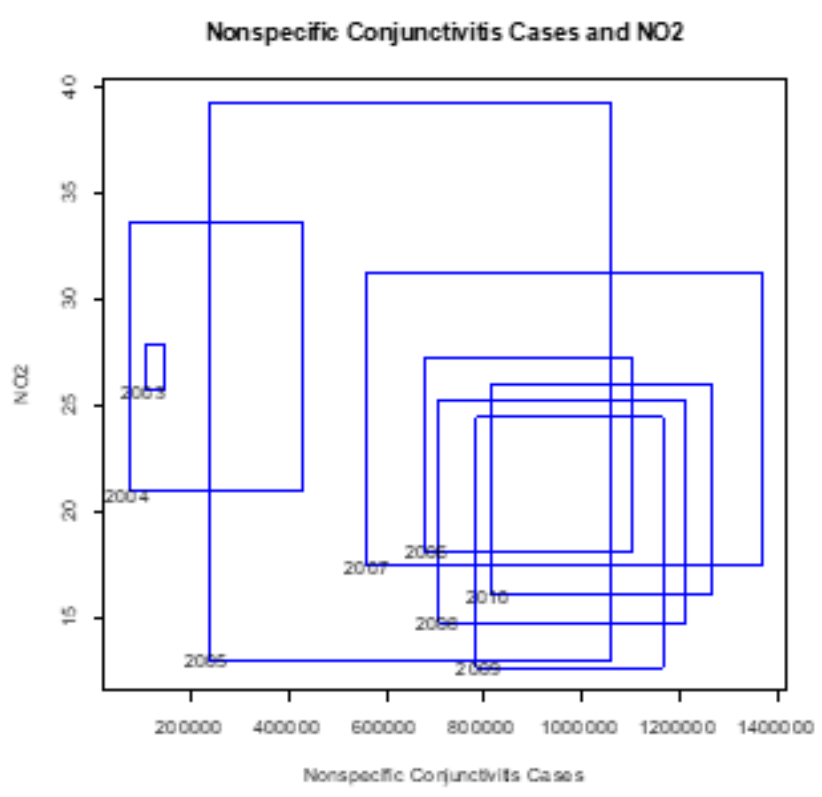

(b) Nonspecific Conjunctivitis Cases with $\mathrm{NO}_{2}$

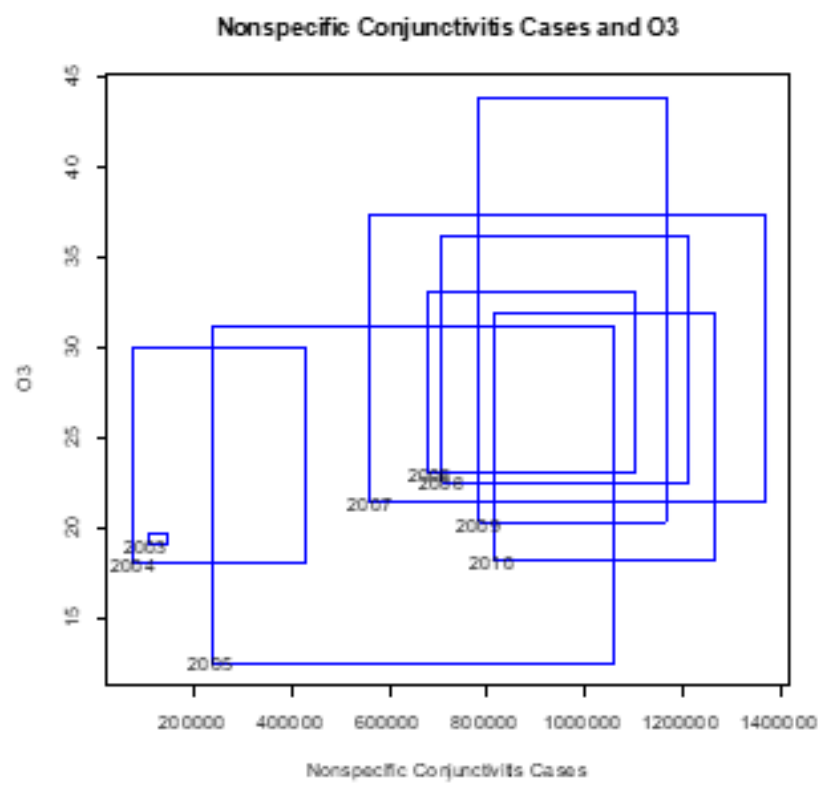

(d) Nonspecific Conjunctivitis Cases with $\mathrm{O}_{3}$

Figure 4: Overall survival time by stage

As for the relationship between $\mathrm{PM}$ and climatic factors, $\mathrm{PM}_{10}$ is not statistically significant with temperature, relative humidity, or rainfall, while $\mathrm{PM}_{2.5}$ is negatively correlated with rainfall ( $\mathrm{t}$-value $=-2.730, \mathrm{p}$-value $\left.=0.008\right)$. The relationship between $\mathrm{PM}_{2.5}$ and temperature / relative humidity is not statistically significant (Table 6).

Based on the results, it can be found that daily temperature is positively correlated with $\mathrm{O}_{3}$ and negatively correlated with CO. Daily rainfall is positively correlated with $\mathrm{SO}_{2}$ and negatively correlated with $\mathrm{PM}_{2.5}$. These results are in agreement with plot (a), (i), and (j) in Figure 2, and plot (f) in Figure 3.

\section{The Relationship between Air Pollutants and the Case of Nonspecific Conjunctivitis}

The relationship between cases of nonspecific conjunctivitis and air pollutants $\left(\mathrm{CO}, \mathrm{NO}_{2}, \mathrm{SO}_{2}\right.$, and $\left.\mathrm{O}_{3}\right)$ by CFA symbolic scatter plots is illustrated in Figure 3. The predictive model plots nonspecific conjunctivitis incidence (cases) versus air pollutants $\left(\mathrm{CO}, \mathrm{NO}_{2}, \mathrm{SO}_{2}\right.$, and $\left.\mathrm{O}_{3}\right)$ in Equation (1).

Table 7 demonstrates that air pollutants are associated with nonspecific conjunctivitis cases, and the regression model plots the nonspecific conjunctivitis incidence (cases) versus $\mathrm{CO}, \mathrm{NO}_{2}, \mathrm{SO}_{2}$, and $\mathrm{O}_{3}$ in Equation (16). The R-squared of Equation (16) is 0.180 , and Adjusted R-squared is 0.134 . 
Table 7: Symbolic regression analysis of air pollutants affecting nonspecific conjunctivitis cases in Taipei

\begin{tabular}{ccccc}
\hline & Estimate & S.E. & t-value & p-value \\
\hline (Intercept) & 207.481 & 15.434 & 13.444 & $<0.001$ \\
\hline $\mathrm{CO}$ & -9.370 & 7.923 & -1.183 & 0.240 \\
\hline $\mathrm{NO}_{2}$ & 0.224 & 0.343 & 0.653 & 0.516 \\
\hline $\mathrm{SO}_{2}$ & -0.437 & 0.464 & -0.942 & 0.349 \\
\hline $\mathrm{O}_{3}$ & 0.377 & 0.164 & 2.292 & 0.025 \\
\hline
\end{tabular}

Table 8: Symbolic regression analysis of particulate matter affecting nonspecific conjunctivitis cases in Taipei

\begin{tabular}{ccccc}
\hline & Estimate & S.E. & t-value & p-value \\
\hline (Intercept) & 227.734 & 8.693 & 26.197 & $<0.001$ \\
\hline $\mathrm{PM}_{10}$ & 0.004 & 0.028 & 0.170 & 0.866 \\
\hline $\mathrm{PM}_{2.5}$ & -0.177 & 0.161 & -1.103 & 0.273 \\
\hline
\end{tabular}

nonspecific conjunctivitis $=207.481+(-9.370) * \mathrm{CO}+0.224 * \mathrm{NO}_{2}+(-0.437) * \mathrm{SO}_{2}+0.377 * \mathrm{O}_{3}$

$\mathrm{O}_{3}$ (t-value $=2.292, \mathrm{p}$-value $\left.=0.025\right)$ is positively correlated with nonspecific conjunctivitis cases; this result is the same as plot $(\mathrm{d})$ in Figure 3. The relationship between nonspecific conjunctivitis cases and $\mathrm{CO}$ ( $\mathrm{t}$-value $=-1.183, \mathrm{p}$-value $=0.240$ ) $/ \mathrm{NO}_{2}(\mathrm{t}-$ value $=0.653, \mathrm{p}$-value $=0.516) / \mathrm{NO}_{2}(\mathrm{t}$-value $=0.653, \mathrm{p}$-value $=0.516) / \mathrm{SO}_{2}(\mathrm{t}$-value $=-0.942, \mathrm{p}$-value $=0.349)$ is not statistically significant.

Based on the result and plot (d) in Figure 2, it can be found that the higher the level of $\mathrm{O}_{3}$, the more the cases of nonspecific conjunctivitis occur.

\section{The Relationship between Particulate Matter and the Case of Nonspecific Conjunctivitis}

The predictive model equation plots nonspecific conjunctivitis incidence (cases) versus $P M\left(P_{10}\right.$ and $\left.\mathrm{PM}_{2.5}\right)$ in Equation (2).

The results demonstrate that air pollutants are associated with nonspecific conjunctivitis cases as shown in Table $\mathbf{8}$, and the regression model equation plots the nonspecific conjunctivitis incidence (cases) versus $\mathrm{PM}_{10}$, and $\mathrm{PM}_{2.5}$ in Equation (17). The R-squared of Equation (17) is 0.016 , and Adjusted R-squared is 0.007 .

$$
\text { nonspecific conjunctivitis }=227.734+0.004 * \mathrm{PM}_{10}+(-0.177) * \mathrm{PM}_{2.5}
$$

Based on the result, the relationship between nonspecific conjunctivitis cases and $\mathrm{PM}_{10}$ ( $\mathrm{t}$-value=1.070, $\mathrm{p}$ value $=0.866) / \mathrm{PM}_{2.5}(\mathrm{t}$-value $=-1.103, \mathrm{p}$-value $=0.273)$ are not significantly correlated.

\section{DISCUSSION AND CONCLUSIONS}

\section{The Relationship between Air Pollutants and the Case of Nonspecific Conjunctivitis}

Previous studies exploring the relationship between air pollution and respiratory disorders have shown that air pollution can induce and worsen respiratory disorders (23). Some studies consider conjunctival mucosa and respiratory mucosa react similarly to exogenous stimuli (24). Respiratory morbidity has been shown to associate with groups of air pollutants, including two or more of $\mathrm{CO}, \mathrm{NO}_{2}, \mathrm{SO}_{2}, \mathrm{O}_{3}$, and $\mathrm{PM}$ (25). The present study's results exhibit partly similar patterns in agreement with the investigations of respiratory disorders.

In this study, the result shows that the air pollutant, $\mathrm{O}_{3}$ is significantly related to nonspecific conjunctivitis. The more the increase of the level of $\mathrm{O}_{3}$, the more nonspecific conjunctivitis cases occur. This result is similar with the studies of Bourcier, Viboud, Cohen, Thomas, Bury, Cadiot, Mestre, Flahault, Borderie, and Laroche (9), Chang, Yang, Chang, and Tsai (12), Szyszkowicz, Kousha, and Castner (14), and Hong, Zhong, Li, Xu, Ye, Mu, Lu, Mashaghi, Zhou, Tan, Li, Sun, Liu, and $\mathrm{Xu}(15)$.

Andrés, García, Espina, Valero, and Valls determine the influence of air pollution on the tear $\mathrm{pH}$. Changes in the lacrimal $\mathrm{pH}$, caused by the acidification of tears in an atmosphere with a high-oxidant power, could irritate the ocular surface (26). O3 can cause severe irritation of respiratory tract mucosa, and the effects are also apparent on ocular mucosa.

Most studies show that PM significantly affects the respiratory system (25). In this study, no association with the case of nonspecific conjunctivitis was found for $\mathrm{PM}_{10}$ and $\mathrm{PM}_{2.5}$. This is possibly due to the effect of tears cleansing the ocular surface. The pollutants of PM that reach the ocular surface do not cause a change in $\mathrm{pH}$ as do other aerosol pollutants. (12) PM can be cleared out of the ocular surface. 


\section{The Relationship between Climate Factors and Air Pollutants}

With regard to the relationship between climate factors and air pollutants, it can be seen that daily temperature is positively correlated with $\mathrm{O}_{3}$ but negatively correlated with $\mathrm{CO}$. And daily rainfall is positively correlated with $\mathrm{SO}_{2}$ but negatively correlated with $\mathrm{PM}_{2.5}$. Many studies indicated that temperature is positively correlated with the cases of nonspecific conjunctivitis $(9,13,15)$. This might be because temperature is positively correlated with the level of $\mathrm{O}_{3}$, and the level of $\mathrm{O}_{3}$ is in turn correlated with nonspecific conjunctivitis.

\section{Conclusions}

This study combined and integrated air pollution and ophthalmologic data to investigate associations between outpatient visits for nonspecific conjunctivitis and air pollution levels. It has found that the air pollutant, $\mathrm{O}_{3}$ can increase chances of outpatient visits, suggesting that it is a possible cause for nonspecific conjunctivitis. Furthermore, this paper has also shown that a favorable air-pollution-monitoring infrastructure combined with established public health data can provide valuable information for an examination of adverse health effects related to air pollution.

\section{REFERENCES}

1. Yue S, Wang Y, Wang J, Chen J. Relationships between lung cancer incidences and air pollutants. Technology and Health Care 2017; 25(S1): 411-422. https://content.iospress.com/articles/technology-and-healthcare/thc1344 PMid:28582929

2. Dehghani M, Keshtgar L, Javaheri MR, Derakhshan Z, Conti GO, Zuccarello P, Ferrante M. The effects of air pollutants on the mortality rate of lung cancer and leukemia. Molecular Medicine Reports 2017; 15(5): 33903397. https://doi.org/10.3892/mmr.2017.6387 PMid:28339039

3. Li R, Jiang N, Liu Q, Huang J, Guo X, Liu F, Gao Z. Impact of Air Pollutants on Outpatient Visits for Acute Respiratory Outcomes. International Journal of Environmental Research and Public Health 2017; 14(1). http://www.mdpi.com/1660-4601/14/1/47 PMid:28067786 PMCid:PMC5295298

4. Deng H, Eckel S P, Liu L, Lurmann FW, Cockburn MG, Gilliland FD. Particulate matter air pollution and liver cancer survival. International Journal of Cancer 2017; 141(4): 744-749. https://doi.org/10.1002/ijc.30779 PMid:28589567 PMCid:PMC5505313

5. Merklinger-Gruchala A, Jasienska G, Kapiszewska M. Effect of Air Pollution on Menstrual Cycle Length-A Prognostic Factor of Women's Reproductive Health. International Journal of Environmental Research and Public Health 2017; 14(7). http://www.mdpi.com/1660-4601/14/7/816 PMid:28726748 PMCid:PMC5551254

6. Word Health Organization. Air pollution, Health topics. [online] [accessed 2019-01-01]. Available from: 2017. http://www.who.int/topics/air_pollution/en/

7. Tuominen ISJ, Konttinen YT, Vesaluoma MH, Moilanen JAO, Helinto M, Tervo TMT. Corneal Innervation and Morphology in Primary Sjögren's Syndrome. Investigative Ophthalmology \& Visual Science 2003; 44(6): 25452549. https://iovs.arvojournals.org/article.aspx?articleid=2163467 PMid:12766055

8. Wang J, Fonn D, Simpson TL, Jones L. Precorneal and Pre- and Postlens Tear Film Thickness Measured Indirectly with Optical Coherence Tomography. Investigative Ophthalmology \& Visual Science 2003; 44(6): 2524-2528. https://iovs.arvojournals.org/article.aspx?articleid=2162911 PMid:12766052

9. Bourcier T, Viboud C, Cohen JC, Thomas F, Bury T, Cadiot L, Mestre O, Flahault A, Borderie V, Laroche L. Effects of air pollution and climatic conditions on the frequency of ophthalmological emergency examinations. The British Journal of Ophthalmology 2003; 87(7): 809-811. https://doi.org/10.1136/bjo.87.7.809 PMid:12812873 PMCid:PMC1771754

10. Novaes P, do Nascimento Saldiva PH, Kara-José N, Macchione M, Matsuda M, Racca L, Berra A. Ambient Levels of Air Pollution Induce Goblet-Cell Hyperplasia in Human Conjunctival Epithelium. Environmental Health Perspectives 2007; 115(12): 1753-1756. https://doi.org/10.1289/ehp.10363 PMid:18087595 PMCid:PMC2137119

11. Gerometta R, Podos SM, Danias J, Candia OA. Steroid-induced ocular hypertension in normal sheep. Investigative $\begin{array}{llllll}\text { Ophthalmology } \quad \& \quad & \text { Visual } & \text { Science } & \text { 2009; } & \text { 50(2): } & \text { 669-673. }\end{array}$ https://iovs.arvojournals.org/article.aspx?articleid=2185262 PMid:18824726

12. Chang CJ, Yang HH, Chang CA, Tsai HY. Relationship between Air Pollution and Outpatient Visits for Nonspecific Conjunctivitis. Clinical and Epidemiologic Research 2012; 53(1): 429-433. https://iovs.arvojournals.org/article.aspx?articleid=2127180 PMid:22205603 
13. Mimura T, Ichinose T, Yamagami S, Fujishima H, Kamei Y, Goto M, Takada S, Matsubara M. Airborne particulate matter (PM2.5) and the prevalence of allergic conjunctivitis in Japan. Science of the Total Environment 2014; 487: 493-499. https://doi.org/10.1016/j.scitotenv.2014.04.057 PMid:24802272

14. Szyszkowicz M, Kousha T, Castner J. Air pollution and emergency department visits for conjunctivitis: A casecrossover study. International Journal of Occupational Medicine and Environmental Health 2016; 29(3): $381-393$. https://doi.org/10.13075/ijomeh.1896.00442 PMid:26988878

15. Hong J, Zhong T, Li H, Xu J, Ye X, Mu Z, Lu Y, Mashaghi A, Zhou Y, Tan M, Li Q, Sun X, Liu Z, Xu J. Ambient air pollution, weather changes, and outpatient visits for allergic conjunctivitis: A retrospective registry study, Scientific Reports 2016; 6. https://www.nature.com/articles/srep23858.pdf PMid:27033635 PMCid:PMC4817244

16. Choi Y, Tang CS, Mclver L, Hashizume M, Chan V, Abeyasinghe RR, Iddings S, Huy R. Effects of weather factors on dengue fever incidence and implications for interventions in Cambodia, BMC Public Health 2016; 16(241). https://bmcpublichealth.biomedcentral.com/articles/10.1186/s12889-016-2923-2

PMid:26955944 PMCid:PMC4784273

17. Wongkoon S, Jaroensutasinee $M$, Jaroensutasinee K. Distribution, seasonal variation and dengue transmission prediction in Sisaket, Thailand. The Indian Journal of Medical Research 2013; 138(3): 347-353. https://www.ncbi.nlm.nih.gov/pmc/articles/PMC3818597/

18. Billard L, Diday E. Symbolic Data Analysis: Conceptual Statistics and Data Mining. West Sussex, England: WileyInterscience; 2007. PMCid:PMC1782305

19. Diday E, Monique NF. Symbolic Data Analysis and the SODAS Software, West Sussex, England: WileyInterscience; 2008.

20. Patz JA, Epstein PR, Burke TA, Balbus JM. Global climate change and emerging infectious diseases. The Journal of the American Medical Association 1996; 275(3): 217-223. https://jamanetwork.com/journals/jama/articleabstract/394508 PMid:8604175

21. Lima-Neto EA, de Carvalho FAT. Centre and range method to fitting a linear regression model on symbolic interval data. Computational Statistics and Data Analysis 2008; 52: 1500-1515. https://doi.org/10.1016/j.csda.2007.04.014

22. Lima-Neto, EA, de Carvalho, FAT. Constrained linear regression models for symbolic interval-valued variables. Computational Statistics and Data Analysis 2010; 54, 333-347. https://doi.org/10.1016/j.csda.2009.08.010

23. Brauer M, Hoek G, Van Vliet P, Meliefste K, Fischer PH, Wijga A, Koopman LP, Neijens HJ, Gerritsen J, Kerkhof M, Heinrich J, Bellander T, Brunekreef B. Air pollution from traffic and the development of respiratory infections and asthmatic and allergic symptoms in children. American Journal of Respiratory and Critical Care Medicine 2002 ; 166(8): 1092-1098. https://doi.org/10.1164/rccm.200108-0070C PMid:12379553

24. Bielory L, Friedlaender MH. Allergic conjunctivitis. Immunology and Allergy Clinics of North America 2008; 28(1): 43-58. https://doi.org/10.1016/j.iac.2007.12.005 PMid:18282545

25. Analitis A, Katsouyanni K, Dimakopoulou K, Samoli E, Nikoloulopoulos AK, Petasakis Y, Touloumi G, Schwartz J, Anderson HR, Cambra K, Forastiere F, Zmirou D, Vonk JM, Clancy L, Kriz B, Bobvos J, Pekkanen J. Short-term effects of ambient particles on cardiovascular and respiratory mortality. Epidemiology 2006; 17(2): $230-233$. https://journals.Iww.com/epidem/Fulltext/2006/03000/Short_Term_Effects_of_Ambient_Particles_on.20.aspx PMid:16477266

26. Andrés S, García ML, Espina M, Valero J, Valls O. Tear $\mathrm{pH}$, air pollution, and contact lenses. American Journal of Optometry and Physiological Optics 1988; 65(8): 627-631. https://europepmc.org/abstract/med/3177587

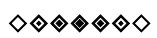

http://www.ejgm.co.uk 